\title{
Pengaruh Intellectual Capital dan Penerapan Prinsip Good Governance oleh Pengelola Barang Milik Negara terhadap Penerapan Manajemen Aset Tetap
}

\author{
Iwan Awaludin a , Harry Suharman ${ }^{\mathrm{b}}$, Fury Khristianty Fitriyah ${ }^{\mathrm{c}^{*}}$ \\ ${ }^{\mathrm{a}, \mathrm{b}}$ Universitas Padjadjaran, Indonesia \\ ${ }^{\mathrm{c}}$ Universitas Padjadjaran, fury@unpad.ac.id, Indonesia
}

\begin{abstract}
Penelitian ini bertujuan untuk membuktikan dan menjelaskan pengaruh positif intellectual capital dan penerapan prinsip good governance terhadap penerapan manajemen aset tetap. Unit analisis penelitian ini adalah Kantor Kementerian Agama Kabupaten/Kota dan Kantor Wilayah Kementerian Agama di Provinsi Jawa Barat. Populasi dalam penelitian ini adalah para pengelola Barang Milik Negara di Kantor Kementerian Agama Kabupaten/Kota dan Kantor Wilayah Kementerian Agama di Provinsi Jawa Barat serta auditor Inspektorat Wilayah II Inspektorat Jenderal Kementerian Agama. Sampel yang digunakan dalam penelitian ini sebanyak 84 responden dengan metode sampling jenuh dan pengujian hipotesis analisis regresi linear berganda. Hasil pengujian hipotesis mengungkapkan bahwa intellectual capital dan penerapan prinsip good governance berpengaruh positif signifikan secara parsial terhadap penerapan manajemen aset tetap, artinya peningkatan intellectual capital dan pelaksanaan prinsip good governance akan memperbaiki manajemen aset tetap. Hasil pengujian juga mengungkapkan intellectual capital dan penerapan prinsip good governance berpengaruh positif signifikan secara simultan terhadap penerapan manajemen aset tetap. Berdasarkan hasil penelitian ini, maka dalam rangka meningkatkan manajemen aset tetap di Kantor Kabupaten/Kota dan Kantor Wilayah Kementerian Agama Provinsi Jawa Barat, pengelola BMN harus meningkatkan kemampuan sumber daya manusia, struktural kelembagaan dan hubungan kelembagaan serta melaksanakan prinsip-prinsip good governance.
\end{abstract}

Keywords: intellectual capital, good governance, manajemen aset tetap

\section{Pendahuluan}

Perubahan paradigma baru pengelolaan atas barang milik negara/aset negara ditandai dengan terbitnya Peraturan Pemerintah Nomor 27 Tahun 2014 tentang Pengelolaan Barang Negara/Daerah. Selanjutnya semangat perubahan tersebut ditindaklanjuti oleh Kementerian Keuangan dengan menerbitkan beberapa peraturan turunannya berupa Peraturan Menteri Keuangan, Surat Edaran, sampai dengan Petunjuk Teknis tentang pengelolaan Barang Milik Negara di Kementerian/Lembaga. Seluruh peraturan tersebut sudah dapat memberikan petunjuk pelaksanaan yang cukup memadai mulai dari ruang lingkup perencanaan kebutuhan, penggunaan sampai dengan pelaporan. Namun dengan banyaknya peraturan tersebut tidak menjamin pengelolaan Barang Milik Negara menjadi lebih baik. Pada tahun 2016 Badan Pemeriksa Keuangan (BPK) memberikan opini Wajar Dengan Pengecualian (WDP) terhadap Laporan Keuangan Pemerintah Pusat tahun 2015. Opini ini belum meningkat sejak tahun 2009. Badan Pemeriksa Keuangan menemukan permasalahan yang terjadi hampir setiap tahun masih didominasi masalah pengelolaan barang milik negara. Penyebab utamanya adalah permasalahan klasik seperti manajemen

\footnotetext{
*Corresponding author. E-mail: fury@unpad.ac.id
} 
sumber daya manusia, ketidakpedulian dalam pemeliharaan aset dan penatausahaan barang milik negara yang tidak baik.

Menurut Agung Firman Sampurna (2016) sebagai Anggota I Badan Pemeriksa Keuangan (BPK), mengatakan bahwa mekanisme penyusunan Laporan Barang Milik Negara (LBMN) dalam rangka mendukung penyajian neraca dalam laporan keuangan belum memadai serta penyajian realisasi belanja modal tidak mencerminkan keadaan fisik yang sebenarnya, terjadi kelebihan pembayaran atas realisasi belanja modal, serta terdapat realisasi belanja barang dan jasa fiktif. Namun demikian, entitas yang mengalami penurunan opini mengindikasikan adanya penurunan akuntabilitas, kurangnya kompetensi dalam pengelolaan keuangan negara khususnya dalam bidang pengadaan barang dan jasa, penatausahaan aset dan perbendaharaan. Menurut Harry Azhar Azis (2016) selaku ketua Badan Pemeriksa Keuangan (BPK) dalam pemeriksaan Laporan Keuangan Pemerintah Pusat (LKPP) Tahun 2015, BPK menemukan 22 (dua puluh dua) permasalahan yang menjadi pengecualian atas LKPP. Permasalahan tersebut merupakan gabungan, 14 (empat belas) kelemahan Sistem Pengendalian Intern (SPI), dan 8 (delapan) ketidakpatuhan terhadap ketentuan peraturan perundang-undangan dalam pelaporan keuangan. Hal yang sama terjadi juga pada Laporan Keuangan Kementerian Agama pada tahun 2015 mendapatkan opini Wajar Dengan Pengecualian (WDP). Terjadi penurunan opini setelah sebelumnya Kementerian Agama untuk keempat kalinya secara berturut-turut berhasil memperoleh opini Wajar Tanpa Pengecualian (WTP) Dengan Paragraf Penjelasan (DPP) atas hasil pemeriksaan Badan Pemeriksa Keuangan (BPK) terhadap Laporan Keuangan Kementerian Agama (LKKA) Tahun 2014. Terkait hal ini, Nur Syam (2015) selaku Sekretaris Jenderal Kementerian Agama menegaskan bahwa ke depan Kementerian Agama akan terus berbenah untuk memperbaiki bagian-bagian yang masih mendapat catatan dari BPK.

Direktur Barang Milik Negara (BMN) Direktorat Jenderal Kekayaan Negara (DJKN) Chalimah Pujihastuti (2016) mengatakan bahwa dewasa ini pengelolaan kekayaan negara tidak hanya berkutat pada isu 3T (Tertib Administrasi, Hukum, dan Fisik), melainkan sudah pada era managing asset. Hal inilah yang telah digaungkan Direktorat Jenderal Kekayaan Negara (DJKN). Pemahaman tugas sebagai Aset Manager yang menekankan proses manajemen mulai planning hingga controlling baik sebagai pengelola barang maupun pengguna barang. Lu (2011) menyebutkan, dalam menerapkan manajemen aset yang baik, terdapat 6 (enam) landasan manajemen aset yang harus dibangun, yaitu persyaratan hukum dan peraturan, struktur organisasi, manajemen aset tetap pada seluruh siklus hidup aset, strategi sumberdaya manusia, manajemen sumberdaya informasi dan teknologi, dan pengawasan, integritas dan transparansi dalam manajemen aset. Hal yang sama dengan pendapat Lutchman (2006) yang menyebutkan bahwa manajemen aset merupakan optimalisasi dari siklus hidup dari aset untuk mendapatkan kinerja standar dalam pengamanan dan perilaku terhadap lingkungan kerja melalui perencanaan yang cerdas, investasi keuangan, teknis, operasi, pemeliharaan, pembaharuan dan pendistribusian.

Penelitian yang dilakukan oleh Muhammad Hasbi Hanis, Bambang Trigunarsyah, dan Connie Susilawati (2011) di Pemerintah Provinsi Sulawesi Selatan mencoba mengidentifikasi tantangan yang dihadapi pemerintah daerah di Indonesia saat mengadopsi Public Asset Management Framework. Saat ini tantangan yang dihadapi pemerintah dalam menerapkan manajemen aset adalah tidak adanya kerangka hukum dan kelembagaan, sikap pemerintah daerah terhadap aset publik, lintas yurisdiksi dalam manajemen aset, kompleksitas tujuan dari organisasi publik, inefisiensi ekonomi terkait aset publik, tidak adanya data yang diperlukan untuk manajemen aset, dan keterbatasan sumber daya manusia.

Berbeda dengan Abdel Hamid, Beshara, dan Ghoneim (2015) yang melakukan penelitian mengenai pengembangan dan penerapan Strategic Asset Management Framework (SAMF) untuk meningkatkan kinerja gedung pendidikan di Egypt. Penelitian ini menyimpulkan bahwa people and organization dan data and information system menempati posisi competence, sedangkan strategic planing dan process and practice menempati level systematic approach. SAMF ini memperkenalkan 3 dimensi yaitu manajemen level, lifecycle function, dan SAM requirement.

Penelitian Dwi Palupi (2015) menyimpulkan beberapa kelemahan dalam manajemen aset yaitu tidak adanya kebijakan umum yang mengatur manajemen aset dan standar kebutuhan barang, lemahnya perencanaan, sumber daya manusia yang kurang memahami manajemen aset, data aset yang tidak akurat serta lemahnya sistem pengawasan. Sedangkan Fluorina (2015) mengemukakan faktorfaktor yang berkaitan dengan optimalisasi aset adalah komitmen pimpinan, integritas dan kejujuran satuan kerja dalam mengungkapkan permasalahan Barang Milik Negara. Selain itu juga manajemen aset 
memerlukan sumber daya manusia yang cukup dan kompeten, koordinasi antara bagian perencanaan, pengadaan dan pelaporan, dan kesadaran atau kepedulian seluruh pegawai terhadap Barang Milik Negara.

Penelitian serupa dilakukan oleh Yusdira Yusof (2013) pada Pemerintah Malaysia merumuskan kerangka pedoman pada area yang perlu ditingkatkan dalam manajemen aset yang dapat diaplikasikan di Malaysia. Dari hasil analisis, dapat disimpulkan bahwa tingkat kesadaran dan pemahaman Total Asset Management Manual (TAMM) belum dapat diterapkan secara efektif baik oleh manajer aset maupun operator. Penelitian mengidentifikasi perlu adanya usaha yang lebih, kebijakan, pelatihan yang berkelanjutan, jangka waktu yang memadai, dan on the job training untuk memperkenalkan TAMM kepada semua pihak yang terlibat dalam rangka mencapai tujuan.

Tuntutan penerapan good governance dalam manajemen aset saat ini sudah tidak dapat ditundatunda lagi. Tentunya hal tersebut akan membuka pemahaman kita bersama tentang urgensi dan pentingnya kegiatan inventarisasi dan reevaluasi BMN itu, sehingga dapat diharapkan mampu meningkatkan status opini Laporan Keuangan Pemerintah Pusat (LKPP) yang semula masih Wajar Dengan Pengecualian (WDP) menjadi unqualified opinion atau Wajar Tanpa Pengecualian (WTP). Sudah saatnya kita berubah menjadi negara yang mampu menerapkan fungsi penganggaran sebagaimana yang telah ditetapkan menurut peraturan yang telah dibuat agar akuntabilitas keuangan pemerintah dapat dipertanggungjawabkan.

Penataan pengelolaan barang milik negara/daerah yang sesuai dengan semangat good governance tersebut, saat ini menjadi momentum yang tepat karena mendapat dukungan politik dari pemerintah. Pentingnya inventarisasi dan reevaluasi aset negara yang ada saat ini sebagai bagian dari penyempurnaan manajemen aset negara secara keseluruhan. Di samping itu, seperti disinggung di atas, penanganan aset negara yang mengikuti kaidah-kaidah good governance akan menjadi salah satu modal dasar yang penting dalam penyusunan Laporan Keuangan yang akuntabel.

Penelitian Atikah et.al. (2014) mengungkapkan bahwa penerapan prinsip-prinsip good governance sangat penting dalam pengelolaan barang milik daerah di Kota Mataram. Sedangkan menurut Grubisic et al, (2009) pemerintah perlu membangun lingkungan untuk perbaikan, profesionalisme dan tanggung jawab dalam manajemen aset publik. Untuk itu, prinsip transaparansi, tanggung jawab dan akuntabilitas pemerintah yang dikenal sebagai good governance adalah hal utama dalam manajemen sektor publik yang efisien. Selanjutnya Hasan Ouda (2015) menuturkan bahwa transparansi, akuntabilitas, dan keterbukaan dalam pelaporan dan pengungkapan informasi tentang public capital asset, baik secara operasional maupun finansial, merupakan penerimaan umum sebagai hal yang penting bagi pelaksanaan good public governance untuk mencapai New Public Management (NPM) dan New Public Financial Management (NPFM).

Tujuan utama dalam ekonomi yang berbasis pengetahuan adalah untuk menciptakan value added. Sedangkan untuk dapat menciptakan value added dibutuhkan ukuran yang tepat tentang physical capital (yaitu dana-dana keuangan) dan intellectual potential (direpresentasikan oleh karyawan dengan segala potensi dan kemampuan yang melekat pada mereka). Lebih lanjut bahwa intellectual ability menunjukkan bagaimana kedua sumber daya tersebut (physical capital dan intellectual potential) telah secara efisiensi dimanfaatkan oleh perusahaan agar dapat memberikan keunggulan kompetitif dan kinerja yang berkelanjutan. Mouritsen, Jan, et.al. (2004) dalam penelitiannya membahas tentang peran intellectual capital dalam membangun new public management pada sektor pemerintahan di Denmark. Penelitian ini menyarankan kepada pemerintah Denmark untuk menggunakan model intellectual capital aktvitas dalam membangun new public management dengan strategi dan model yang telah dilakukan di sektor swasta, sehingga ada nilai tambah sebagaimana perusahaan swasta dalam mengembangkan bisnisnya.

Penelitian Agnes Utari dan Anni Aryani (2013) menyatakan bahwa perusahaan yang dapat mempertahankan keunggulan kompetitifnya mempunyai kemampuan dalam menciptakan nilai tambah bagi stakeholder dan mengelola aset stratejiknya yang bersifat VRIN (Valuable, Rare, Inimitable, and Non-substitutable) dengan efisien. Sedangkan Bontis, et.al (2000), Cheng, et.al. (2010), dan Chang et.al. (2011) dalam penelitiannya menyimpulkan bahwa human capital, structural capital, and social capital adalah peran yang signifikan dalam menciptakan nilai untuk stakeholder dan terdapat hubungan signifikan antara intellectual capital dengan kinerja perusahaan. 


\section{Kajian Pustaka, Kerangka Pemikiran, Hipotesis}

\section{Kajian Pustaka}

Financial Accounting Standard Board mendefinisikan aset sebagai kemungkinan manfaat ekonomi masa depan yang akan diperoleh atau dikendalikan entitas sebagai akibat dari transaksi atau kejadian di masa lalu (Lu, 2011). Dari perspektif sektor publik, Pernyataan Nomor 07 Standar Akuntansi Pemerintahan mendefinisikan aset sebagai:

"Sumber daya ekonomi yang dikuasai dan/atau dimiliki oleh pemerintah sebagai akibat dari peristiwa masa lalu dan dari mana manfaat ekonomi dan/atau sosial dimasa depan diharapkan dapat diperoleh, baik oleh pemerintah maupun masyarakat, serta dapat diukur dalam satuan uang, termasuk sumber daya nonkeuangan yang diperlukan untuk penyediaan jasa bagi masyarakat umum dan sumber-sumber daya yang dipelihara karena alasan sejarah dan budaya" (Peraturan Pemerintah Nomor 71 Tahun 2010, paragraf 32).

Definisi Manajemen Aset menurut Hastings (2010:3)

"Asset Management is the set of activities associated with: Identifying what assets are needed, identifying funding requirements, acquiring assets, providing logistic and maintenance support system for assets, disposing or renewing assets. So as to effectively and efficiently meet the desired objective." Menurut Terri Hart-Sears dalam white papernya yaitu Why Good Data Is A Must: Asset Management Oversight is Essential to Effective Governance "Asset Management is a set of business practices that join financial, contractual and inventory functions to support asset life cycle management and strategic decision making for the IT environment." (Hart-Sears, 2012:1)

Menurut Hastings (2010:6) tahapan manajemen aset tetap meliputi:

1. Identifying what assets are needed

2. Identifying funding requirements

3. Acquiring Assets

4. Providing logistic (operation) and maintenance support systems for assets

5. Disposing or renewing assets

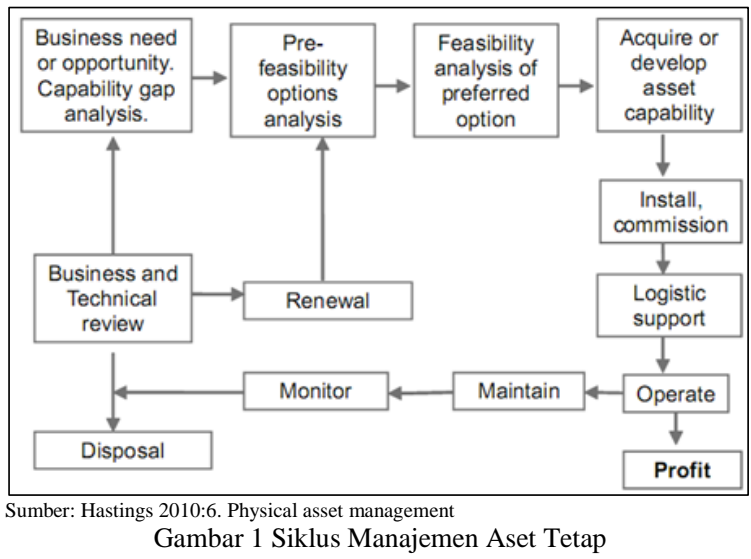

Pelaksanaan manajemen aset tetap yang efisien dan efektif akan mendukung pencapaian tujuan organisasi dalam pemberian pelayanan kepada publik. Untuk menjamin manajemen aset tetap dilaksanakan dengan baik, entitas perlu menerapkan pengawasan terhadap pelaksanaannya. Semua barang yang diperoleh atau dibeli atas beban APBN atau dari perolehan yang sah lainnya merupakan Barang Milik Negara (Pemerintah Republik Indonesia, 2014). Pengawasan Barang Milik Negara mengandung pengertian bahwa proses penetapan ukuran keberhasilan dan pengambilan tindakan yang mendukung kesesuaian ketercapaian hasil dengan tujuan yang telah ditetapkan (BPKP, 2007). Pengawasan secara manajerial dapat dilakukan melalui implementasi sistem pengendalian intern pemerintah (SPIP). Sedangkan dari pihak eksternal, pengawasan dilakukan oleh Badan Pemeriksa Keuangan selaku auditor eksternal pemerintah. Dalam pemeriksaan atas laporan keuangan, pengelolaan Barang Milik Negara (BMN) merupakan salah satu unsur yang menjadi kriteria pemeriksaan.

Salah satu definisi intellectual capital yang banyak digunakan adalah yang ditawarkan oleh Organisation for Economic Co-operation and Development (OECD, dalam Utari dan Anni, 2013) menjelaskan bahwa intellectual capital sebagai nilai ekonomi dari dua kategori aset tak berwujud: (1) organisational (structural) capital; dan (2) human capital. Menurut Cheng, et al. (2010) intellectual capital merupakan sumber daya kunci dan penggerak (driver) atas kinerja serta penciptaan nilai perusahaan, sehingga intellectual capital berperan penting dalam menciptakan maupun mempertahankan keunggulan kompetitif. Sharabati et.al. (2010) mendefinisikan intellectual capital sebagai "packaged useful knowledge" yang merupakan sumber daya berupa pengetahuan yang tersedia pada perusahaan yang 
menghasilkan aset bernilai tinggi dan manfaat ekonomi di masa mendatang bagi perusahaan.

Menurut pendapat Stewart (1997), Curado dan Bontis (2009), dan Sharabati et.al. (2010), konsep intellectual capital terdiri dari tiga dimensi yaitu: human capital, relational capital and structural capital.

Menurut Mardiasmo (2006), governance dapat diartikan sebagai mekanisme, praktek dan tata cara mengelola dan mengatur sumber daya dalam masalahmasalah publik. Sedangkan World Bank memberikan definisi governance sebagai "the way state power is used in managing economic and social resources for development of society". Dalam hal ini World Bank lebih menekankan pada cara pemerintah mengelola sumber daya social dan ekonomi untuk kepentingan pembangunan masyarakat. (Mardiasmo, 2006:17).

Good Governance sebagai suatu bentuk manajemen pembangunan, yang juga disebut sebagai adminstrasi pembangunan, yang menempatkan peran pemerintah sentral yang menjadi Agent of change dari suatu masyarakat berkembang/developing di dalam negara berkembang. Agent of change karena perubahan yang dikehendakinya, menjadi planned change (perubahan yang berencana), maka disebut juga Agent of Development. Agent of Development diartikan sebagai pendorong proses pembangunan dan perubahan masyarakat bangsa.

\section{Kerangka Pemikiran}

Pengaruh Penerapan Good Governance Terhadap Manajemen Aset Tetap

Deegan (2004) menyebutkan bahwa berdasarkan teori stakeholder, manajemen organisasi diharapkan untuk melakukan aktivitas yang dianggap penting oleh stakeholder mereka dan melaporkan kembali aktivitas-aktivitas tersebut pada stakeholder (Deegan dalam Ulum, 2007). Lebih lanjut Deegan (2004) dalam Ulum (2007) menyatakan bahwa teori stakeholder menekankan akuntabilitas organisasi jauh melebihi kinerja keuangan atau ekonomi sederhana. Teori ini menyatakan bahwa organisasi akan memilih secara sukarela mengungkapkan informasi tentang kinerja lingkungan, sosial dan intelektual mereka, melebihi dan di atas permintaan wajibnya, untuk memenuhi ekspektasi sesungguhnya atau yang diakui oleh stakeholder.

Penerapan prinsip-prinsip good governance merupakan suatu keharusan bagi pelaksanaan pengelolaan Barang Milik Negara, hal ini disebutkan dalam Peraturan Pemerintah Nomor 27 Tahun 2014 pasal 3 yang berbunyi pengelolaan Barang Milik Negara dilaksanakan berdasarkan asas fungsional, kepastian hukum, transparansi, efisiensi, akuntabilitas, dan kepastian nilai.

Lu (2011) menyebutkan pentingnya penerapan prinsip good governance dalam manajemen aset tetap. Penerapan dalam pengawasan manajemen aset tetap dapat dilakukan dalam beberapa hal, yaitu pengawasan ketaatan terhadap peraturan perundangan, pengawasan terhadap efektifitas kebijakan dan prosedur, dan pengawasan terhadap akuntabilitas finansial. Manajer aset harus memiliki responsibilitas, integritas dan transparansi dalam melaksanakan manajemen aset tetap yang baik, sehingga keputusan dalam manajemen aset tetap dapat dipertanggungjawabkan terhadap internal dan eksternal stakeholder dan untuk menjamin bahwa manajemen aset tetap dilaksanakan secara efisien dan efektif serta akuntabel.

Menurut Hassan Ouda (2015) bahwa public sector assets management harus memenuhi syarat good governace diantaranya transparency, accountability and openness in reporting and disclosure of information. Sedangkan menurut M. Grubišic et.al. (2009) prinsip transparansi, professional dan responsible adalah syarat utama untuk efisiensi public sector assets management.

Penelitian yang dilakukan oleh Hindarwan, et.al. (2006) yang menyatakan bahwa dengan menerapkan manajemen aset yang efektif, pemerintah dapat memperbesar manfaat aset dengan memastikan kerangka hukum dan kelembagaan, pemanfaatan dan pemeliharaan secara layak, menghemat pengeluaran melalui pemilihan alternatif solusi non aset, memperoleh nilai uang yang lebih besar melalui penilaian ekonomis atas pilihan yang diambil dan keterlibatan sektor swasta, mengurangi pengadaan melalui pertimbangan biaya siklus hidup aset, dan memfokuskan perhatian pada pembebanan tanggung jawab, akuntabilitas dan pelaporan yang jelas.

Berdasarkan paparan di atas maka kerangka pemikiran dalam penelitian ini adalah sebagai berikut:

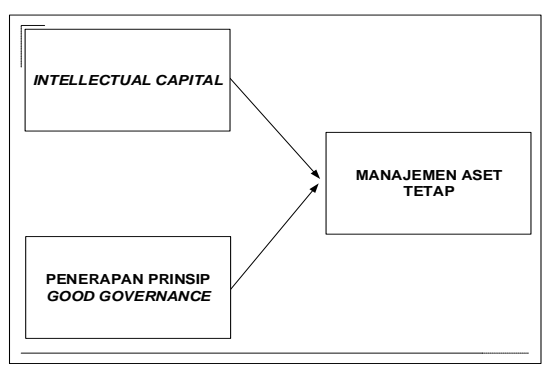

Gambar 2 Kerangka Pemikiran 


\section{Hipotesis}

Hipotesis yang akan diuji dan dibuktikan dalam penelitian ini berkaitan dengan ada tidaknya pengaruh positif antara variabel bebas dengan variabel terikat. Hipotesis yang diajukan sebagai berikut:

Hipotesis 1: Intellectual capital berpengaruh positif terhadap pelaksanaan manajemen aset tetap.

Hipotesis 2: Penerapan prinsip good governance berpengaruh positif terhadap pelaksanaan manajemen aset tetap.

Hipotesis 3: Intellectual capital dan penerapan prinsip good governance secara simultan berpengaruh positif terhadap pelaksanaan manajemen aset tetap.

\section{Metode Penelitian}

\section{Objek Penelitian}

Objek penelitian yang dikemukakan oleh Sugiyono (2011:38) adalah suatu atribut atau sifat atau nilai dari orang, obyek atau kegiatan yang mempunyai variasi tertentu yang ditetapkan oleh peneliti untuk dipelajari dan kemudian ditarik kesimpulannya. Objek dalam penelitian ini meliputi dua macam variabel, yaitu variabel bebas (independent) terdiri dari intellectul capital (X1) dan penerapan prinsip good governance (X2) dan variabel terikat (dependent) terdiri dari penerapan manajemen aset tetap (Y). Model yang digunakan dalam penelitian ini ditinjau dari tingkat eksplanasinya merupakan penelitian bersifat asosiatif, yaitu menjelaskan hubungan dua variabel atau lebih. Jadi penelitian ini merupakan suatu penelitian yang mencari hubungan antara satu variabel dengan variabel yang lain. Hubungan asosiatif antara variabel tersebut adalah hubungan simetris, karena penelitian ini berusaha mengkaji terhadap hubungan satu variabel yang disebut sebagai variabel yang diterangkan (the explained variabel) dengan 2 (dua) variabel yang menerangkan (the explanatory), yaitu pengaruh intellectual capital dan penerapan prinsip good governance akan dikenakan kepada variabel manajemen aset tetap. Unit analisis dalam penelitian adalah satuan tertentu yang diperhitungkan sebagai subjek penelitian. (Arikunto, 2010:89), sehingga unit analisis dalam penelitian ini adalah Kantor Kementerian Kabupaten/Kota dan Kantor Wilayah Kementerian Agama Provinsi Jawa Barat yang sesuai dengan Keputusan Menteri Agama Nomor 15 Tahun
2015 tentang Kebijakan Akuntansi Kementerian Agama. Pada masing-masing unit analisis, ditentukan unit observasi/responden sebagai berikut:

1. Kepala Bagian Provinsi/Kepala Subbagian Tata Usaha Kabupaten/Kota Kementerian Agama, digunakan untuk mengukur variabel intellectual capital dan penerapan prinsip good governance, sebagai pendorong pelaksanaan penerapan manajemen aset tetap.

2. Operator SIMAK BMN Kantor Provinsi/Kabupaten/Kota Kementerian Agama, digunakan untuk mengukur variabel intellectual capital dan penerapan prinsip good governance, sebagai pendorong pelaksanaan penerapan manajemen aset tetap.

3. Tim audit Inspektorat Jenderal Kementerian Agama, digunakan untuk mengukur variabel manajemen aset tetap, sebagai pengguna hasil akhir dari kegiatan manajemen aset tetap untuk materi audit.

\section{Metode Analisis}

Metode analisis yang digunakan dalam penelitian ini adalah:
a. Uji Validitas
b. Uji Reliabilitas
c. Transformasi Data
d. Uji Normalitas
e. Uji Asumsi Klasik

\section{Analisis Data}

Persamaan regresi linier berganda (multiple linier regression) yang digunakan adalah sebagai berikut:

Persamaan Regresi yang digunakan pada penelitian ini dapat dirumuskan sebagai berikut:

$$
\begin{aligned}
& \mathrm{Y}=0,270+0,023 \mathrm{X} 1+0,998 \mathrm{X} 2+\varepsilon \\
& \text { dalam hal ini: } \\
& \mathrm{Y} \quad \text { : Manajemen Aset Tetap } \\
& \mathrm{X} 1 \quad \text { Intellectual Capital } \\
& \mathrm{X} 2 \quad \text { : Prinsip Good Governance } \\
& \mathrm{A} \quad \text { : Intercept (Konstanta) } \\
& \mathrm{b} 1, \mathrm{~b} 2 \\
& \varepsilon \quad \text { Koefisien regresi } \\
& \varepsilon \quad \text { : Error }
\end{aligned}
$$




\section{Hasil dan Pembahasan}

\section{Pengaruh Intellectual Capital Terhadap Manajemen Aset Tetap}

Berdasarkan hasil pengolahan data diperoleh hasil koefisien determinasi sebagai berikut:

Tabel 1 Prosentase Pengaruh Intellectual Capital (X1) dan Good Governance (X2) terhadap Manajemen Aset Tetap (Y)

\begin{tabular}{|c|c|c|}
\hline Pengaruh Variabel & Koefesien & $\begin{array}{c}\text { Kontribusi } \\
\%\end{array}$ \\
\hline X1 terhadap Y & 0.023 & $1.6 \%$ \\
\hline $\mathrm{X} 2$ terhadap $\mathrm{Y}$ & 0.998 & $68.7 \%$ \\
\hline $\mathrm{X} 1$ dan $\mathrm{X} 2$ terhadap $\mathrm{Y}$ & 0.703 & $70.3 \%$ \\
\hline
\end{tabular}

Berdasarkan pengolahan data, bahwa intellectual capital secara parsial berpengaruh positif signifikan dan nilai koefisien untuk intellectual capital (X1) adalah sebesar 0,023, yang artinya bahwa jika intellectual capital mengalami peningkatan maka manajemen aset tetap akan semakin baik.

Besarnya kontribusi pengaruh secara parsial untuk variabel intellectual capital sebesar 0,023 atau 1,6\% dari $70,3 \%$ total pengaruh simultan terhadap manajemen aset tetap pada Kantor Kementerian Agama Kabupaten/Kota dan Kantor Wilayah Provinsi Jawa Barat sesuai variabel dalam penelitian ini, di mana pengaruh intellectual capital (X1) terhadap manajemen aset tetap (Y) adalah sebesar 1,6\%, di mana sisanya dipengaruhi faktor penerapan prinsip good governance $68,7 \%$, dan $29,7 \%$ faktor lain diluar variabel penelitian.

Berdasarkan hasil penelitian menunjukkan bahwa intellectual capital pengelola BMN yang ada saat ini dapat mempengaruhi manajemen aset tetap berjalan dengan baik pada Kantor Kementerian Agama Kabupaten/Kota dan Kantor Wilayah Provinsi Jawa Barat. Jika dilihat dari sudut pandang indikator yang digunakan pada penelitian ini, hal ini terjadi karena pengelola BMN mengetahui dengan baik teori secara akademik dalam melaksanakan pekerja sesuai dengan pendidikan, ketelitian dalam melaksanakan prosedur pengelolaan $\mathrm{BMN}$, pengembangan teknologi informasi untuk menunjang pengelolaan BMN, dan koordinasi informasi baik dengan instansi Pembina maupun KPKNL dalam pengelolaan BMN.

Dalam manajemen aset tetap, staf dan manajer aset mempunyai peran penting dalam mengembangkan tujuan manajemen aset tetap dan pencapaian tujuan organisasi. Oleh sebab itu perlu adanya peningkatan capability pengelola aset baik pada tingkat operasional maupun pada tingkat manajerial. Petugas pengelola
BMN harus mengikuti diklat teknis subtantif seperti Program Percepatan Akuntabilitas Keuangan Pemerintah (PPAKP) dan Diklat Teknis Substantif Spesialisasi (DTSS) yang diselenggarakan Kementerian Keuangan dan berbagai sosialisasi dan workshop peraturan terbaru dalam pengelolaan Barang Milik Negara. Diharapkan hal ini dapat meningkatkan kualitas pengelolaan BMN di Kementerian Agama menjadi lebih baik.

Sehubungan dengan pengelolaan informasi secara terkomputerisasi, Kementerian Keuangan selaku pengelola barang membangun aplikasi Sistem Informasi Manajemen dan Akuntansi Barang Milik Negara (Simak-BMN) yang wajib digunakan oleh seluruh instansi pemerintah yang mengkonsolidasikan laporan keuangannya ke Laporan Keuangan Pemerintah Pusat. Simak-BMN merupakan sistem terpadu yang merupakan gabungan prosedur manual dan komputerisasi dalam rangka menghasilkan data transaksi untuk mendukung penyusunan neraca. Simak-BMN diselenggarakan dengan tujuan untuk menghasilkan informasi yang diperlukan sebagai alat pertanggungjawaban atas pelaksanaan APBN serta pengelolaan dan pengendalian Barang Milik Negara yang dikuasai oleh suatu unit akuntansi barang. Di samping menghasilkan informasi sebagai dasar penyusunan Neraca Kementerian, Simak-BMN juga menghasilkan informasi-informasi untuk memenuhi kebutuhan pertanggungjawaban pengelolaan Barang Milik Negara dan kebutuhan-kebutuhan manajerial kementerian negara/lembaga lainnya.

Koordinasi yang lemah antara KPKNL dengan satuan kerja pengelola dalam hal penetapan status penggunaan Barang Milik Negara yang dikuasai menyebabkan lemahnya aspek legal dan administrasi yang dicapai dalam manajemen aset tetap. Kualitas manajemen aset tetap pada sebuah organisasi tergantung pada hukum dan peraturan yang mendasarinya. Selanjutnya hukum dan peraturan dijabarkan dalam kerangka manajemen aset strategis, petunjuk dan prosedur yang digunakan sebagai guidance dalam melaksanakan manajemen aset tetap secara akuntabel.

Manfaat dari adanya lingkungan pengendalian yang kondusif, utamanya adalah mendorong tersedianya seluruh pengelola aset negara yang memiliki kesadaran (awareness) yang kuat tentang pentingnya penegakan sistem pengendalian intern. Penciptaan ini dilakukan melalui penegakan integritas dan nilai-nilai etika oleh seluruh pegawai, komitmen terhadap kompetensi setiap komponen organisasi, adanya kepemimpinan yang kondusif, tersusunnya struktur organisasi yang mendukung strategi pencapaian 
tujuan, adanya pendelegasian wewenang dan tanggung jawab yang tepat, kebijakan yang sehat dalam pembinaan sumber daya manusia, adanya peran APIP yang efektif dan hubungan kerja yang baik antar instansi.

Hasil penelitian ini senada dengan penelitian yang dilakukan oleh Lu (2011), yang menyatakan bahwa dalam menerapkan manajemen aset yang baik, terdapat landasan manajemen aset yang harus dibangun, diantaranya adalah struktur organisasi, strategi sumber daya manusia, manajemen sumber daya informasi dan teknologi dalam manajemen aset. Jika landasan manajemen aset tersebut ditingkatkan maka manajemen aset akan lebih baik. Selain penelitian yang di lakukan Lu (2011) di atas, hal senada diungkap Yusof (2013) merumuskan kerangka pedoman yang perlu ditingkatkan dalam manajemen aset tetap yaitu, kebijakan, pelatihan yang berkelanjutan, jangka waktu yang memadai, dan on the job training.

Selain penelitian yang dilakukan Lu (2011) di atas, hal senada diungkap oleh Hasbi M. Hanis et.al (2011) mengidentifikasi tantangan yang dihadapi pemerintah daerah di Indonesia dalam menerapkan manajemen aset adalah tidak adanya kerangka hukum dan kelembagaan, sikap pemerintah daerah terhadap aset publik, lintas yurisdiksi dalam manajemen aset, kompleksitas tujuan dari organisasi publik, inefisiensi ekonomi terkait aset publik, tidak adanya data yang diperlukan untuk manajemen aset, dan keterbatasan sumber daya manusia.

Dalam pengelolaan keuangan negara secara umum menurut penelitian Palmer, Kristine N, et al (2013) bahwa kompetensi harus dimiliki oleh pengelola keuangan sebagaimana yang diperlukan dalam pelaporan keuangan seperti pengetahuan, keahlian, dan kemampuan untuk level awal akuntan adalah keahlian komunikasi, keahlian interpersonal, pengetahuan bisnis umum, pengetahuan akuntansi, keahlian dalam menyelesaikan masalah, teknologi informasi, perilaku pribadi dan capability, serta keahlian komputer.

Dalam sasaran kinerja pegawai seorang pengelola BMN menyebutkan bahwa kinerja pengelola BMN adalah tercapainya tertib administrasi, hukum, dan fisik dalam pengelolaan BMN sehingga dapat terwujud manajemen aset tetap sesuai dengan amanat Peraturan Pemerintah Nomor 27 Tahun 2014 Tentang Pengelolaan Barang Milik Negara dan Daerah. Hal ini sejalan dengan Rencana Strategi Kementerian Agama Tahun 2015-2019 yang menyebutkan bahwa Biro Keuangan dan BMN Kementerian Agama dalam pengelolaan BMN akan mewujudkan peningkatan kualitas Laporan Keuangan Kementerian Agama. Langkah-langkah yang ditempuh antara lain menyusun strategy dan action plan peningkatan kualitas Laporan Keuangan Kementerian Agama. Empat strategi peningkatan kualitas Laporan Keuangan Kementerian Agama dilakukan melalui rekrutmen tenaga akuntansi, penataan aset dan penyelamatan BMN, pembuatan sertifikat tanah bagi aset tanah Kementerian Agama yang belum ada bukti kepemilikannya, pengembalian aset-aset yang dikuasai oleh pihak ketiga, serta menyusun sejumlah regulasi yang berkaitan dengan Laporan Keuangan beserta penyusunan standar operasional penyusunan Laporan Keuangan Kementerian Agama pada setiap jenjang pelaporan.

\section{Pengaruh Penerapan Prinsip Good Governance Terhadap Manajemen Aset Tetap}

Berdasarkan pengolahan data, bahwa penerapan prinsip good governance secara parsial berpengaruh positif signifikan dan nilai koefisien untuk penerapan prinsip good governance (X2) adalah sebesar 0,998, yang artinya bahwa jika penerapan prinsip good governance mengalami peningkatan maka manajemen aset tetap akan semakin baik.

Besarnya pengaruh kontribusi pengaruh secara parsial untuk variabel penerapan prinsip good governance sebesar 0,998 atau $68,7 \%$ dari $70,3 \%$ total pengaruh simultan terhadap manajemen aset tetap pada Kantor Kementerian Agama Kabupaten/Kota dan Kantor Wilayah Provinsi Jawa Barat sesuai variabel dalam penelitian ini, di mana pengaruh penerapan prinsip good governance (X2) terhadap manajemen aset tetap (Y) adalah sebesar $68,7 \%$, di mana sisanya dipengaruhi faktor intellectual capital $1,6 \%$, dan $29,7 \%$ faktor lain di luar variabel penelitian.

Hasil penelitian ini menunjukkan bahwa penerapan prinsip good governance oleh pengelola $\mathrm{BMN}$ yang ada saat ini dapat mempengaruhi manajemen aset tetap dilaksanakan dengan baik pada Kantor Kementerian Agama Kabupaten/Kota dan Kantor Wilayah Provinsi Jawa Barat. Jika dilihat dari sudut pandang indikator yang digunakan pada penelitian ini, hal ini terjadi karena pelaksanaan peraturan pengelolaan BMN dengan baik, pengungkapan (disclosure) yang jujur dalam laporan $\mathrm{BMN}$, dalam pengelolaan $\mathrm{BMN}$ menggunakan biaya yang serendah-rendahnya untuk mencapai tujuan dan sasaran akhir kebijakan, kesesuaian antara pelaksanaan dengan standar prosedur, kesesuaian antara pelaksanaan dengan 
standar prosedur, dan pembuatan laporan pertanggungjawaban sesuai dengan peraturan.

Pelaksanaan prinsip-prinsip good governance bertujuan untuk mewujudkan tertib administrasi pengelolaan BMN dalam penetapan status penggunaan, pemanfaatan, penghapusan, dan pemindahtanganan Barang Milik Negara di lingkungan Kementerian Agama secara efektif dan efisien dengan berpegang teguh pada prinsip yang tidak merugikan keuangan negara dan sesuai dengan ketentuan perundang-undangan yang berlaku. Pelaksanaan tersebut berkaitan dengan:

1. Pelaksanaan pengelolaan BMN yang berdasarkan atas ketaatan hukum dan peraturan yang berlaku;

2. Transparansi dalam pelaksanaan maupun pengungkapan (disclosure) pengelolaan BMN;

3. Efektifitas dan efisiensi dalam pelaksanaan pengelolaan BMN mulai dari perencanaan, pelaksanaan, pelaporan dan pengawasan pengelolaan BMN;

4. Akuntabilitas pengelolaan $\mathrm{BMN}$ dalam pelaksanaan pengelolaan BMN mulai dari perencanaan, pelaksanaan, pelaporan dan pengawasan pengelolaan BMN;

5. Perencanaan dan pelaksanaan pengelolaan BMN atas dasar pendekatan yang lebih sistematis dan logis dalam menganggarkan belanja pemeliharaan atau belanja modal untuk mengganti atau menambah aset tetap yang sudah dimiliki pada satu tahun ke depan.

Pelaksanaan budaya kerja dapat menjadi energi bagi pengelola $\mathrm{BMN}$ dalam melaksanakan tugas dan fungsinya, yang mendukung nilai transparansi dan akuntabilitas dalam pengelolaan BMN. Faktor utama yang sangat berpengaruh adalah penerapan pada 5 (lima) nilai budaya kerja yang menjadi program revolusi mental pada Kementerian Agama yaitu 1) integritas, 2) profesional, 3) inovasi, 4) tanggung jawab, dan 5) keteladanan dalam rangka mewujudkan tata kelola kepemerintahan yang baik (good governance). Hal ini menjadi landasan kuat bagi semua pengelola BMN di Kementerian Agama untuk menjamin terlaksananya manajemen aset tetap yang baik. Di samping itu, lebih lanjut seperti disinggung di atas, penanganan aset negara yang mengikuti kaidahkaidah tata kelola yang baik (good governance) akan menjadi salah satu modal dasar yang penting dalam penyusunan Laporan Keuangan Kementerian Agama yang akuntabel.

Hasil penelitian ini senada dengan penelitian yang dilakukan oleh Lu (2011), yang menyatakan bahwa persyaratan hukum dan peraturan, manajemen aset tetap pada seluruh siklus hidup aset, pengawasan, integritas dan transparansi dalam manajemen aset merupakan landasan untuk meningkatkan manajemen aset tetap lebih baik. Jika landasan tersebut mengalami peningkatan maka manajemen aset tetap akan lebih baik. Selain penelitian yang dilakukan Lu (2011) di atas, hal senada diungkap Hassan Ouda (2015) bahwa public sector assets management harus memenuhi syarat good governace diantaranya transparency, accountability and openness in reporting and disclosure of information. Sedangkan menurut M. Grubišic et.al. (2009) prinsip transparansi, profesional dan responsible adalah syarat utama untuk efisiensi public sector assets management.

Penelitian ini juga senada dengan yang dilakukan oleh Hindarwan, et.al. (2006) yang menyatakan bahwa dengan menerapkan manajemen aset yang efektif, pemerintah dapat memperbesar manfaat aset dengan memastikan kerangka hukum dan kelembagaan, pemanfaatan dan pemeliharaan secara layak, menghemat pengeluaran melalui pemilihan alternatif solusi non aset, memperoleh nilai uang yang lebih besar melalui penilaian ekonomis atas pilihan yang diambil dan keterlibatan sektor swasta, mengurangi pengadaan melalui pertimbangan biaya siklus hidup aset, dan memfokuskan perhatian pada pembebanan tanggung jawab, akuntabilitas dan pelaporan yang jelas.

Selanjutnya, dalam rangka menciptakan transparansi dan akuntabilitas dalam pengelolaan dan pertanggungjawaban keuangan negara dan Barang Milik Negara menjamin terlaksananya tertib administrasi dan pengelolaan Barang Milik Negara di Kantor Kementerian Agama Kabupaten/Kota dan Kantor Wilayah Provinsi Jawa Barat diperlukan adanya kesamaan persepsi dan langkah secara integral dan menyeluruh dari unsur-unsur yang terkait dalam pengelolaan Barang Milik Negara. Penerapan prinsipprinsip good governance merupakan suatu keharusan bagi pelaksanaan pengelolaan Barang Milik Negara, hal ini disebutkan dalam Peraturan Pemerintah Nomor 27 Tahun 2014 pasal 3 yang berbunyi pengelolaan Barang Milik Negara dilaksanakan berdasarkan asas fungsional, kepastian hukum, transparansi, efisiensi, akuntabilitas, dan kepastian nilai.

Berdasarkan pembahasan hasil pengujian hipotesis tersebut, dapat diketahui bahwa aspek kapabilitas sumber daya manusia, aspek struktural kelembagaan, dan aspek relational kelembagaan yang terdapat dalam intellectual capital merupakan komponen pokok yang mempengaruhi dalam penerapan manajemen aset tetap. Selain aspek utama tersebut, aspek pendukung teknis yaitu penerapan prisnisp-prinsip good governance merupakan faktor yang dapat 
meningkatkan penerapan manajemen aset tetap di Kantor Kementerian Agama Kab/Kota dan Kantor Wilayah Kementerian Agama Provinsi Jawa Barat. Hal ini menjadi satu kesatuan yang membentuk sebuah kinerja guna mendukung terwujudnya Laporan Barang Milik Negara dan Neraca yang handal dan akurat dalam konteks pengelolaan keuangan negara.

\section{Penutup}

\section{Kesimpulan}

Berdasarkan hasil pengujian dan analisis yang telah dilakukan pada bab sebelumnya, maka dapat disimpulkan sebagai berikut:

1. Intelectual capital berpengaruh positif signifikan terhadap manajemen aset tetap. Selanjutnya dari hasil pengujian hipotesis tersebut, dapat diketahui pengetahuan, keahlian, dan kemampuan untuk level awal akuntan, strategi sumber daya manusia, struktur organisasi, manajemen sumber daya informasi dan teknologi dalam manajemen aset, koordinasi antar bagian, sistem pengawasan menunjukkan pengaruh yang besar terhadap penerapan manajemen aset tetap.

2. Penerapan prinsip good governance berpengaruh positif signifikan terhadap manajemen aset tetap. Selanjutnya dari hasil pengujian hipotesis tersebut, dapat diketahui persyaratan hukum dan peraturan, lintas yurisdiksi dalam manajemen aset, integritas dan transparansi dalam manajemen aset, transparency, accountability dan openness in reporting and disclosure of information menunjukkan pengaruh yang besar terhadap penerapan manajemen aset tetap.

\section{References}

Abdelhamid, M., Beshara, I., \& Ghoneim, M. (2015). Strategic Asset Management: Assessment Tool for Educational Building in Egypt. HBRC Journal Vol 11, 98-106.

Arikunto, Suharsimi. (2010). Manajemen Penelitian. Jakarta: Penerbit Rineka Cipta.

Atikah Siti, Saipul Am dan Bq. Anggun Hilendri Lestari. (2014). Penerapan Prinsip-Prinsip Good Governance dalam Pengelolaan Barang Milik Daerah (Studi Pada Pemerintah Daerah Kota Mataram), Jurnal Universitas Mataram.

Australian National Audit Office. (2010). Better Practice Guide on the Strategic and Operational Management of Assets by Public Sector Entities. Canberra: The Publications Manager of ANAO.
Berman Howard J. (2006). Public Trust and Good Governance: an Essay. Inquiry-excellus health plan. Vol.43: Proquest pg.6.

Badan Pemeriksaan Keuangan. (2015). Laporan Hasil Pemeriksaan BPK RI Nomor: 19B/LHP/XVIII/05/2015, 08 Mei 2015. Jakarta.

Badan Pemeriksa Keuangan, (2015). Ikhtisar Hasil Pemeriksaan Semester I Tahun 2015. Jakarta.

Badan Pemeriksaan Keuangan. (2016). LKPP Tahun 2015 Yang Berbasis Akrual Mempeoleh Predikat WDP. http://www.bpk.go.id/news/lkpp-tahun-2015-yangberbasis-akrual-mempeoleh-predikat-wdp.

Badan Pemeriksa Keuangan. (2016). Serahkan LHP kepada $19 \mathrm{~K} / \mathrm{L}$, BPK Berharap Tindak Lanjut Rekomendasi BPK Segera Dilakukan. Jakarta: Badan Pemeriksa Keuangan http://www.bpk.go.id/news/serahkan-lhp-kepada-19-klbpk-berharap-tindak-lanjut-rekomendasi-bpk-segeradilakukan.

Barney, J. B. and Clark, D. N. (2007). Resource-based Theory: Creating and Sustaining Competitive Advantage. New York: Oxford University Press, Inc.

Bontis, Nick. (2000). Assessing Knowledge Assets: A Review of the Models Used to Measure Intellectual Capital. Canada: School of Business, McMaster University.

Bontis, N., Keow, W. and Richardson, S. (2000). Intellectual capital and the nature of business in Malaysia. Journal of Intellectual Capital, 1(1), pp. 85-100.

Chang, William S. dan Jasper J, Hsieh. 2011. Intellectual Capital and Value Creation Is Innovation Capital a missing Link? International Journal of Bussiness and Management, $6(2)$

Cheng, M., Lin, J., Hsiao, T., and Lin, T. W. (2010). Invested Resource, Competitive Intellectual Capital, and Corporate Performance. Journal of Intellectual Capital, 11(4), 433-450

Curado, Carla. dan Nick Bontis. (2007). Managing Intellectual Capital: the MIC Matrix. International Journal of Knowledge and Learning, 3(2/3), pp. 316-28.

Dewi Hilda Gustrina. (2012). Analisis Hasil Audit BPK-RI Atas Aset Tetap pada Laporan Keuangan Kementerian/Lembaga. Tesis. Universitas Indonesia.

Desi Indriasari dan Ertambang Nahartyo. (2008). Pengaruh Kapasitas Sumberdaya Manusia, Pemanfaatan Teknologi Informasi, dan Pengendalian Intern Akuntansi terhadap Nilai Informasi Pelaporan Keuangan Pemerintah Daerah (Studi pada Pemerintah Kota Palembang dan Kabupaten Ogan Ilir).

Dias, Marco Antonio Harms, Paula Regina Zarelli, dan Paulo Maurício Selig. (2014). Intellectual Capital and Public Management: A Bibliometric Analysis. Brasil: Journa 
of US-China Public Administration, ISSN 1548-6591, Vol. 11(2), 108-120.

Direktorat Jenderal Kekayaan Negara. (2016). PP Nomor 27 tahun 2014 Fasilitasi Pengelola BMN Menjadi Manajer Aset. https://www.djkn.kemenkeu.go.id/2016/berita/baca/864 5/PP-Nomor-27-Tahun-2014-Fasilitasi-PengelolaBMN-Menjadi-Manajer-Aset.html.

Direktorat Jenderal Kekayaan Negara. (2016). Gugus Kendali Mutu Pengelolaan Barang Milik Negara: Menjadi Manajer Aset yang Menekankan Proses Manajemen. https://www.djkn.kemenkeu.go.id/berita/detail/menjadimanajer-aset-yang-menekankan-proses-manajemen.

Ehrlich Isaac, William A. Hamlen Jr. dan Yong Yin. (2008). Asset Management, Human Capital, and the Market for Risky Asset. Cambridge, Working Paper 14340 http://www.nber.org/papers/w14340.

Erizul dan Febri Yuliani. (2014). Pelaksanaan Pengelolaan Aset Tetap Daerah. Jurnal Administrasi Pembangunan, Universitas Riau, 2(2), Maret 2014, hlm. 115-226.

Fahmi, Irham. (2010). Manajemen Kinerja: Teori dan Aplikasi. Bandung: Alfabeta.

Fluorina. (2015). Analisis Pengawasan dan Pengendalian Barang Milik Negara (Studi Kasus Pada Kementerian Komunikasi Dan Informatika). Tesis. Jakarta: Universitas Indonesia.

Ghozali, Imam. (2012). Aplikasi Analisis Multivariate dengan Program IBM SPSS 20, Cetakan Kelima, Semarang: Badan Penerbit Universitas Diponegoro.

Hadinata, A. (2011). Bahan Ajar Manajemen Aset. Jakarta: Sekolah Tinggi Akuntansi Negara.

Hanis, M. H., Trigunarsyah, B., \& Susilawati, C. (2011). The Application of Public Asset Management in Indonesian Local Government A Case Study in South Sulawesi Province. Journal of Corporate Real Estate, 13(1), 3647.

Hariyanto Wiwit dan Sigit Hermawan. (2015). Pengaruh Intellectual Capital Terhadap Business Performance dan Competitive Advantage pada Perusahaan Farmasi di Jawa Timur. Simposium Nasional Akuntansi 18: Universitas Sumatera Utara, Medan.

Hart-Sears, Terri (2012). Why Good Data is a Must: Asset Management Oversight is Essential to Effective Governancem, edisi pertama. U.S.A: ISG specializing in Consumption Management Services.

Hastings, Nicholas AJ. (2010). Physical Asset Management. Brisbane: Springer.

Hidayat, M. D. (2011). Manajemen Aset (Privat dan Publik). Yogyakarta: Laksbang PRESSindo Yogyakarta.

Hindarwan, I., Hariyono, A., \& Murtaji. (2006). Manajemen Properti: Tinjauan atas Real Properti dan Aset Publik. Jakarta: Badan Pendidikan dan Pelatihan Keuangan.
Ikatan Akuntan Indonesia. (2011). Exposure Draft Pernyataan Standar Akuntansi Keuangan 16 (revisi 2011): Aset Tetap. Jakarta: Dewan Standar Akuntansi Keuangan IAI.

Indra Bastian. (2006). Akuntansi Sektor Publik: Suatu Pengantar. Jakarta: Penerbit Erlangga.

Indriasari, Desi dan Ertambang Nahartyo. (2008). Pengaruh Kapasitas Sumber Daya Manusia, Pemanfaatan Teknologi Informasi, Dan Pengendalian Intern Akuntansi Terhadap Nilai Informasi Pelaporan Keuangan Pemerintah Daerah (Studi Pada Pemerintah Kota Palembang Dan Kabupaten Ogan Ilir). Yogyakarta: Universitas Gajah Mada.

Johnston Michael. (2002). Good Governance: Rule of Law, Transparency, and Accountability. Paper. Colgate University New York.

Kaganova, Olga dan Nayyar Stone, J. (2000). Municipal Real Property Asset . Management: An Overview of World Experience, Trend, and Financial Implication. Washington DC: The Urban Institute Press.

Kaganova, Olga. (2010). Managing Government Capital Assets in the State of California: What Can Be Learned from Other Governments? Washington DC: The Urban Institute Press.

Ketchen, D and Short, J. (2012). Strategic Management: Evaluation and Execution v.1.0. Minnesota: University of Minnesota Libraries Publishing.

Kementerian Agama. (2015). Karokeu dan BMN, Tidak Mudah Capai Target WTP. 30 September 2015. Pinmas Kemenag. $\quad \mathrm{http} / / / \mathrm{id}$ id.facebook.com/KementerianAgamaRI/posts/1015336 2761667928:0.

Kementerian Agama. (2015). Kemenag Berhasil Pertahankan Opini WTP-DPP. 10 Juni 2015. Pinmas Kemenag Kabupaten Magelang.

http://magelang.kemenag.go.id/berita/read/kemenagberhasil-pertahankan-opini-wtp-dpp.

Keputusan Menteri Agama Nomor 15 Tahun 2015 tanggal 30 Januari 2015 tentang Kebijakan Akuntansi Kementerian Agama.

Khan, Muhammad Wasim Jan. (2014). Identifying the Components and Importance of Intellectual Capital in KnowledgeIntensive Organizations. University Malaysia, Sarawak, Malaysia Business and Economic Research. ISSN 2162$4860 \quad$ Vol. $4, \quad$ No. 2 http://dx.doi.org/10.5296/ber.v4i2.6594.

Local Government Victoria. (2004). Asset Management Policy, Strategy and Plan. Melbourne: Department for Victorian Communities.

Lu, Y. (2011). Public Asset Management: Empirical Evidence from the State Governments in the United States. Florida: Florida Atlantic University. 
M. Grubišic, M. Nušinovic and G. Roje. (2009). Towards Efficient Public Sector Asset Management Financial Theory and Practice. Portugal: Comparative International Governmental Accounting Research 33(3) 329-362.

Marr, Bernard. (2008). Impacting Future Value: How to Manage your Intellectual Capital. http:www.cimaglobal.com/Documents/ImportedDocum ents/ tech_mag_impacting_future_value_may08.pdf

Mei-Fen Wu, Yu-Je Lee, dan Gao-Liang Wang. (2012). To Verify How Intellectual Capital Affects Organizational Performance in Listed Taiwan IC Design Companies with considering the moderator of Corporate Governance. Taiwan: The Journal of Global Business Management, Volume 8, February 2012.

Mardiasmo. (2006). Akuntansi Sektor Publik. Jogyakarta: Andi.

Mouritsen, Jan and Stefan Thorbjornsen. (2004). Intellectual Capital and New Public Management: Reintroducing enterprise. Emerald group publishing, vol. 11. No. 4/5.

Nemmers, C. (2004). Transportation Asset Management. Public Roads Magazine. Data accessed at www.tfhrc.gov/pubrds/july97/tam.htm.

Nina Evans and James Price. (2012). Responsibility and Accountability for Information Asset Management (IAM) in Organizations. The Electronic Journal Information Systems Evaluation, 17(1) 2014, (113-121) ISSN 1566-6379 available online at www.ejise.com.

Nugroho, Bhuono Agung. (2005). Strategi Jitu Memilih Metode Statistik Penelitian dengan SPSS. Yogyakarta: Andi Offset.

Ouda, Hassan. (2015). Towards a Practical Holistic Accounting Approach for Governmental Capital Assets: An Accountability and Governance Perspective. Cairo: German University.

Palupi, Dwi. (2015). Analisis Implementasi Manajemen Aset pada Pengelolaan Barang Milik Negara (Studi Kasus pada Kementerian Perindustrian). Tesis. Jakarta: Universitas Indonesia.

Pemerintah Republik Indonesia. (2014). Peraturan Pemerintah Nomor 27 Tahun 2014. Jakarta: Pemerintah Republik Indonesia.

Pemerintah Republik Indonesia. (2010). Peraturan Pemerintah Nomor 71 Tahun 2010 tentang Standar Akuntansi Pemerintah. Jakarta: Pemerintah Republik Indonesia.

Peterson, R. H. (2002). Accounting For Fixed Assets (Second Edition). New York: John Wiley and Sons, Inc.

Riduwan. (2009). Skala Pengukuran Variabel-Variabel Penelitian. Bandung: Alfabeta.

Schuman, C. A., \& Brent, A. C. (2005). Asset Life Cycle Management: towards improving physical asset performance in the process industry. International
Journal of Operations \& Production Management, 25(6), 566-579.

Sedarmayanti. (2009). Sumber Daya Manusia dan Produktivitas Kerja. Bandung: CV. Mandar Maju.

Sekaran, Uma. (2006). Research Method for Business, Metode Penelitian Bisnis. Jakarta: Salemba Empat.

Sharabati, Abdel-Aziz Ahmad, Shawqi Naji Jawad dan Nick Bontis (2010). Intellectual capital and business performance in the pharmaceutical sector of Jordan. Management Decision, 48(1). Emerald Group Publishing Limited.

Sindo News. (2016). BPK Ungkap 6 Permasalahan Laporan Keuangan Pemerintah 2015. http://ekbis.sindonews.com/read/1114372/33/bpkungkap-6-permasalahan-laporan-keuangan-pemerintah2015-1465191938.

Stewart, T.A. (1997). Intellectual Capital: The New Wealth of Organizations. Doubleday/Currency New York.

Sugiyono. (2012). Metode Penelitian Bisnis. Bandung: Alfabeta.

Sukmadilaga Citra, Arie Pratama dan Sri Mulyani. (2015). Good Governance Implementation in Public Sector: Exploratory Analysis of Government Financial Statements Disclosures across ASEAN Countries. 2nd Global Conference on Business and Social Science2015, GCBSS-2015, 17-18 September 2015, Bali, Indonesia.

Sumarto Hetifa Sj. (2003). Inovasi, Partisipasi dan Good Governance. Bandung: Yayasan Obor Indonesia.

Surminah, Lin. (2008). Manajemen Aset di Lembaga Litbang. Warta Kebijakan Iptek \& Manajemen Litbang, penerbit Papiptek-LIPI, Jakarta, 2008:77-94

Tangkilisan, Hessel Nogi. (2005). Manajemen Publik. Jakarta: Grassindo.

The Institute of Asset Management. (2012). Asset Management - an anatomy. London. www.theIAM.org/AMA.

Ulum Ihyaul. (2007). Pengaruh Intellectual Capital terhadap Kinerja Keuangan Perusahaan Perbankan di Indonesia. Semarang: Universitas Diponegoro Semarang.

Universitas Padjadjaran. (2014). Panduan Umum Penyusunan Dan Penulisan Tesis Dan Disertasi Penulisan Artikel Ilmiah Penyusunan Dalil. Bandung: Universitas Padjadjaran.

Utari, Agnes Widyaningdyah dan Y. Anni Aryani. (2013). Intellectual Capital dan Keunggulan Kompetitif (Studi Empiris Perusahaan Manufaktur versi Jakarta Stock Industrial Classification-JASICA). Semarang: Universitas Sebelas Maret.

Yudi, Nurmana Jaya. (2015). Kegiatan Edukasi Proses Penilaian Kepada Kementerian/Lembaga. Jakarta: Kementerian Keuangan https://www.djkn.kemenkeu.go.id/2013/berita/pp- 
nomor-27-tahun-2014-fasilitasi-pengelola-bmn-

menjadi-manajer-aset.

Yusof, Yusdira. (2013). The Effectiveness of Public Sector Asset

Management in Malaysia. Tesis. Brisbane: Queensland University of Technology.

Zeghal, Daniel dan Anis Maaloul. (2010). Analysis value added as an indicator of intellectual capital and its consequences on company performance. Journal of Intellectual Capital, 11(1). 2010 